\title{
Enterprise Resources Planning effectiveness and Organizational Performance: The case of "Jordanian Hashemite fund for human development"
}

\author{
Maha Alkhaffaf \\ World Islamic Sciences and Education University \\ E-mail: alkhaffaf@yahoo.com \\ Mahmood Aldalahmeh \\ Jordan University \\ E-mail: Aldalhmeh2@yahoo.com
}

Received: September 20, 2015 Accepted: October 25, 2015

doi:10.5296/ber.v6i1.8315

URL: http://dx.doi.org/10.5296/ber.v6i1.8315

\begin{abstract}
The study aimed at analysing the impact of Enterprise Resources Planning (ERP) system effectiveness on achieving better organizational performance in the Hashemite foundation for human development by analysing the effectiveness dimensions of ERP system (Information quality, System quality, User satisfaction). In order to achieve the study goal the researchers has designed questionnaire to collect preliminary data, consisting of 25 paragraphs and distributed to the members of the study sample. The study sample contains the entire department that uses ERP in the Jordanian Hashemite fund for human development. The study found a significant relationship between effectiveness of ERP and their combined impact on organizational performance
\end{abstract}

Keywords: ERP system, Effectiveness, Jordanian Hashemite fund for human development (JOHUD)

\section{Introduction}

It has become imperative for organizations to increase the effectiveness in light of the significant global competition, ERP is one of the tools organization must use to increase this 
effectiveness, ERP have been designed to increase and enhance the competitive advantage by providing an accurate information for organization when it needed (Kennerely \& Neel, 2001)

ERP helps an organization to integrate information flows, operations and processes all resources accessible, However many organizations uses ERP software solution to gain integration among departments, functions and even data flow rather than creating a tough customized solution that can accomplish all requirements of business organization.

Different types of organizations today are taking advantages of ERP, on the other hand there are several modules in an ERP software; manufacturing, Finance, human resources, supply chain, customer relationship management, warehouse management etc. moreover ERP software can suite deferent industries, thus the people who are working in some specific industries such as healthcare, manufacturing, garment house, schools, accounts etc. can implement this in their work place.

The Jordanian Hashemite fund for human development (JOHUD) is one of the foundations that has implemented ERP in its different units in Jordan, established in 1977as an independent, leading non-profit, non-governmental organization, dedicated to promoting rights-based sustainable human development in Jordan.

Across Jordan and through a network of 50 community development centres, the approach of JOHUD is place people at the centre of the development process, and encourages them to play a leading role in defining and pursuing their own ideas.

This study was based on the reason that the (JOHUD) has applied ERP systems, aiming to planning and optimum utilization of human and financial resources. The project of ERP system has cost (JOHUD) 200,000 Jordan Dinar of its budget.

This study aims at understand and analyze the role of ERP system on the organizational performance using the ERP effectiveness metrics by considering the ERP effectiveness as an independent factor and the organizational performance as an dependent factor

\section{Background}

An Enterprise Resource Planning (ERP) system is a magic solution organizations can use to integrate its business functions Fosser (2011) and colleagues named the ERP systems as a "Vanilla" software (e.g. an SAP ERP system) that have become the best solution for organization to integrate its business function, his research based on the question what will happen to the competitive advantage if all the organizations uses this solution. Hassabelnaby, Hwang, Vonderembse (2012) examine whether the implementation of ERP impacts both business strategy and organizational capabilities which enhances firm performance, after a secondary data collected from more than 400 firms the study found that ERP implementation has a positive impact when a firm employs a prospector business strategy that will lead to enhances the firm's ability to achieve higher levels of financial performance moreover the study reports the mediating effect of business strategy and organizational capabilities on the relationship between ERP implementation and firm performance. The result of this study was the same of Nicolaou \& Bhattacharya (2006) who found after an empirically examination 
over 247 firms that ERP-adopting firms, which initiate early enhancements in the form of either add-ons or upgrades, may enjoy superior differential financial performance in comparison to other ERP-adopting firms' differential performance, the study tested a hypothesis that has been substantiated in the research that both nature and the timing of ERP systems implementation changes represent significant conditions for ERP post implementation success. Unlike these results Nooredin Etezady (2011) examined the impact of ERP systems implementation on financial performance of public companies over a period of four years and found that ERP implementation did not affect significantly financial performance of the firms that had implemented ERP. This study results can contribute to improved decision-making and setting ERP expectations at the time of ERP purchase. Same as a dissertation in the subject of ERP and its impact on organizational financial performance, the research analysis of data showed that deployment of ERP systems did not affect financial performance of organizations significantly when measured over a four-year post-adoption period, the study two independent variables and four dependent variables that represent organizational performance were defined in the thesis. Return on asset, return on investment, return on sales, and cost of goods sold over sales measured organizational performance. ERP implementation status and ERP scope (independent variables) affected dependent variables. Etezady, Nooredin (2008). Furthermore in the Romanian case study of the best practice Dumitru and colleagues (2013) suggested that the Romanian managers and IT employees to become more aware of how they can leverage their ERP system to exploit its fuller potential, and regarding the importance of the organizational context for the implementation and post implementation processes, this study aims to investigate how the evolution of both organizations and systems transforms the case of ERP implementation in best practices in management and accounting in an emerging economy, the study illustrate how the ERP system in one side and the case organization in another side evolved that consequently led to improving organizational performance.

The dependent variable used in the research model below have been selected based on number of researches made in ERP; (Chain - Son Yu, 2005), (Tsai, W., Chen, S., Hwang, E., \& Hsu, J...2010), (Princely Ifinedo, Nazmun Nahar, 2009)

As for the independents factors was used from number of researcher in the field of organizational performance (Hansen, G. S. and Wernerfelt, B., 1989) (Ababneh, R.A (2008) 


\section{Macrothink}

\section{Research Model}

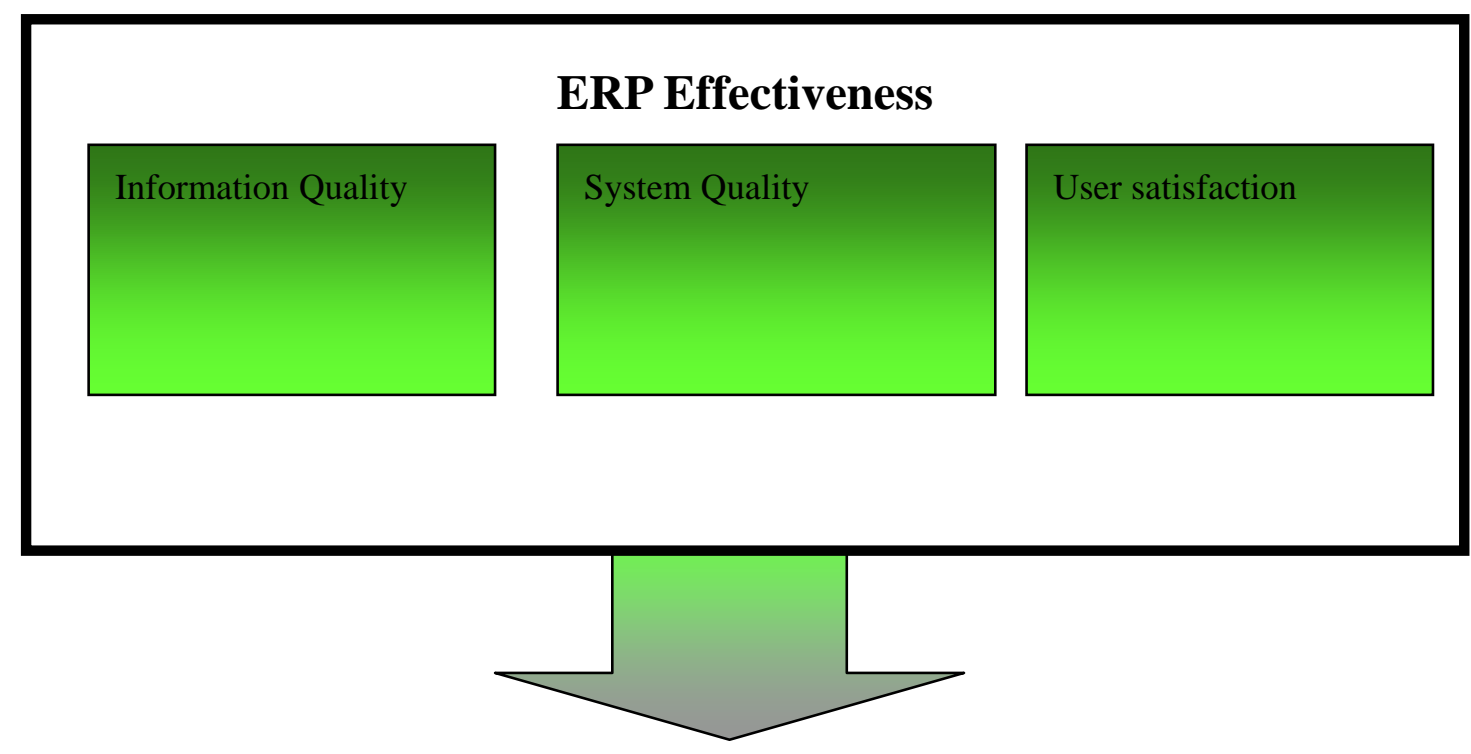

Organizational Performance
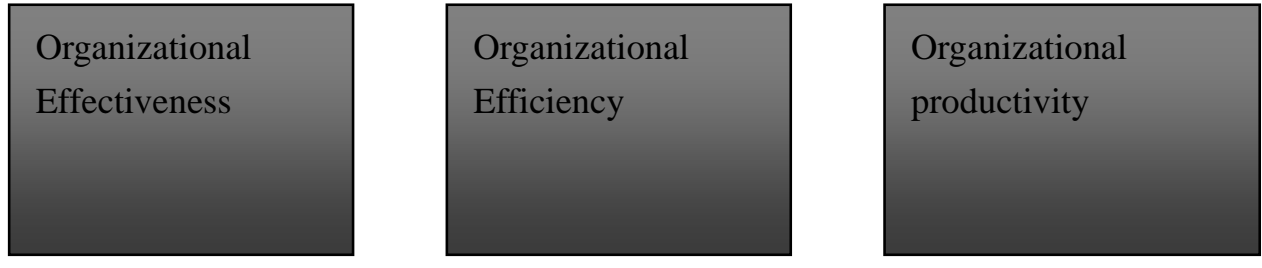

Figure 1

\subsection{Research Methodology}

This study depends on an empirical study, the research model above shows the dependent variable; ERP systems effectiveness measured by information quality, system quality and customer satisfaction, affected by the independent variable the organizational performance measured by organizational effectiveness, organizational efficiency and organizational productivity.

\section{Context and Research Population}

The study population is consisted of all the departments that implement ERP in JOHUD. JOHUD is consisted of 50 units with 678 staff members distributed in ten Province, 12 units only has implemented ERP systems. The 678 staff members are distributed depending to the following percentages according to their field. only the staff who use the ERP has been used in this study; $16.5 \%$ in central offices, $48.2 \%$ in CDCs and the field, $17.6 \%$ in ZENID, $17.7 \%$ other operations. $60 \%$ of JOHUD staff is development professionals and field staff. $40 \%$ of JOHUD staff is administrative support staff. 
200 questionnaires has been distributed in the 12 units of JOHUD, 192 questionnaires were collected. The table below describes the demographic information about the study population according to the distribution of sex, age educational level, the current position in the organization and the years of work with the ERP system

Table 1.Demographic Information

\begin{tabular}{|l|l|l|l|}
\hline Variable & Category & Repetition & $\%$ \\
\hline Sex & Male & 60 & $61 \%$ \\
\hline \multirow{4}{*}{ Age } & Female & 30 & $29 \%$ \\
\cline { 2 - 4 } & Total & 90 & 100 \\
\hline \multirow{5}{*}{ Educational level } & $26-35 \mathrm{Y}$ & 54 & $56 \%$ \\
\hline \multirow{5}{*}{ Current position in Organization } & $36-45 \mathrm{Y}$ & 29 & $30 \%$ \\
\cline { 2 - 4 } & 46 and over & 13 & $13 \%$ \\
\cline { 2 - 4 } & Total & 99 & $99 \%$ \\
\hline & Diploma & 28 & $28 \%$ \\
\hline Years of work with ERP & Manager & 3 & $66 \%$ \\
\hline \multirow{4}{*}{} & Gachelor & 65 & $3 \%$ \\
\cline { 2 - 4 } & Graduates studies & 3 & 100 \\
\hline & Less than one year & 2 & $2 \%$ \\
\hline & $1-3$ years & 90 & $90 \%$ \\
\cline { 2 - 4 } & Total & 92 & $100 \%$ \\
\hline
\end{tabular}

\section{Study Tools and Sources of Information}

In order to collect information about the role of ERP effectiveness in achieving better organizational performance two main resources have been used; the literature written in field of ERP and its relationship to the organizational performance which cover the theoretical side of the study, and the questionnaire that have been designed according to the results of research made in ERP field, this tool have been used order to cover the empirical side of the study.

The questionnaire is consisted of three main parts, the first part include the demographic information divided as mentioned in the figure above. The second part was about the dependant variable; ERP effectiveness measured by three factors; information quality, system quality and customer satisfaction. The third part of the questionnaire was about the independent variable organizational performance that was measured by three factors; effectiveness, efficiency and productivity.

Likert scale have been used because its one of the most commonly used metrics to measure the opinion in studies and it is also easy to understand by respondents. The table below identifies the grades of response used in the study: 
Table 2. Likert scale

\begin{tabular}{|l|l|l|l|l|}
\hline Strongly agree & Agree & Neutral & Don't agree & Strongly don't agree \\
\hline 1 grade & 2 grades & 3 grades & 4 grades & 5 grades \\
\hline
\end{tabular}

In order to answer the study question and to test the research hypothesis number of statistical methods have been used; Cronpagh alpha to test the stability factor, the descriptive statistical methods (mean, duplicates and percentages) to find out the level of each factor, multiple regression and simple regression, the other statistical method that have been used was the correlation coefficient to measure the relatedness of the research variables with each other.

The table below identify the Crombagh Alpha for the study factors to ensure its validity

Table 3 . Cronbach Alpha

\begin{tabular}{|l|l|l|}
\hline The factor & Number of paragraphs & Alpha coefficient \\
\hline Quality of information & 3 & 0.74 \\
\hline Quality of the system & 5 & 0.78 \\
\hline Customer satisfaction & 3 & 0.85 \\
\hline Organizational performance & 15 & 0.75 \\
\hline Mediterranean to the tool as a whole & 25 & 0.79 \\
\hline
\end{tabular}

The table above shows that the alpha was 0.79 so it was grater than the accepted value; (Alpha 0.60).

\section{Hypothesis Testing and Results}

The below section aimed at presenting the result of the statistical analysis that the study has found by using the SPSS.

The following are the results of hypothesis testing divided according to the factors of the research model

\subsection{Results Presentation of the Factor of Effectiveness of the ERP Systems According To the Quality of Information}

The standard deviation, average and the level of evaluation of paragraphs have been used to test the factor of ERP effectiveness according to the factor of information quality. The table bellows identify these values according to the response of the study population (canters that uses ERP systems in JOHUD)

Table 4. Testing the ERP system effectiveness paragraphs according to information quality

\begin{tabular}{|l|l|l|l|l|l|l|}
\hline The paragraph & Average & $\begin{array}{l}\text { Standard } \\
\text { deviation }\end{array}$ & T test & $\begin{array}{l}\text { Level of } \\
\text { evaluation }\end{array}$ & $\begin{array}{l}\text { The } \\
\text { paragraph }\end{array}$ & $\begin{array}{l}\text { The importance } \\
\text { of paragraph }\end{array}$ \\
\hline $\begin{array}{l}\text { The information that I get } \\
\text { form ERP is } \\
\text { understandable }\end{array}$ & 4.021 & 0.31 & 121.361 & High & 1 & 1 \\
\hline The number of errors in the & 4.01 & 0.37 & 89.51 & High & 2 & 3 \\
\hline
\end{tabular}




\begin{tabular}{|l|l|l|l|l|l|l|}
\hline ERP systems is acceptable & & & & & & \\
\hline $\begin{array}{l}\text { The information of ERP } \\
\text { covers different areas in } \\
\text { my work }\end{array}$ & 4.00 & 0.41 & 110.31 & High & 3 & 2 \\
\hline The overall average & 4.01 & & & & \\
\hline
\end{tabular}

Table 4 above present the analysis of the paragraphs about the information quality depending on the response of the study population (centers that uses the ERP system in JOHUD) where the averages ranged from (4.00 and 4.021) comparing to the overall average of this factor that equal (4.01) in which the paragraph (The information that I get form ERP is understandable) get the first importance level with the average of (4.021) and with (0.31) standard deviation comparing to the overall average (4.01). On the other hand the paragraph (The number of errors in the ERP systems is acceptable) has get the least importance level with average (4.01) and (0.37) standard deviation, comparing to the overall average (4.01) for the factor of information quality. However the averages of the all the paragraphs was high.

\subsection{Results Presentation of the Factor of Effectiveness of the ERP Systems According To the Quality of the System}

The standard deviation, average and the level of evaluation of paragraphs have been used to test the factor of ERP effectiveness according to the factor of system quality. The table bellows identify these values according to the response of the study population (centers that uses ERP systems in JOHUD.

Table 5. Testing the ERP system effectiveness paragraphs according to systems quality

\begin{tabular}{|l|l|l|l|l|l|l|}
\hline The paragraph & Average & $\begin{array}{l}\text { Standard } \\
\text { deviation } \\
\text { test }\end{array}$ & $\begin{array}{l}\text { T } \\
\text { evaluation } \\
\text { paragraph }\end{array}$ & $\begin{array}{l}\text { The } \\
\text { importance } \\
\text { paragraph }\end{array}$ \\
\hline $\begin{array}{l}\text { The ERP information is valuable } \\
\text { for different managerial } \\
\text { decisions }\end{array}$ & 3.84 & 0.55 & 68 & High & 1 & 4 \\
\hline $\begin{array}{l}\text { The ERP system is flexible in } \\
\text { which it can deal with different } \\
\text { situations and circumstances }\end{array}$ & 3.89 & 0.59 & 72 & High & 2 & 3 \\
\hline $\begin{array}{l}\text { The ERP system can help in } \\
\text { achieving employee needs }\end{array}$ & 3.80 & 0.53 & 62 & High & 3 & 5 \\
\hline $\begin{array}{l}\text { The ERP system provide the } \\
\text { needed information in the mean } \\
\text { time }\end{array}$ & 3.90 & 0.58 & 65 & High & 4 & 2 \\
\hline $\begin{array}{l}\text { The ERP is an ease to use } \\
\text { system }\end{array}$ & 4.07 & 0.44 & 90 & High & 5 & 1 \\
\hline \begin{tabular}{l} 
The overall average \\
\hline
\end{tabular} & 3.9215
\end{tabular}

Table 5 above present the analysis of the paragraphs about the system quality depending on the response of the study population (centres that uses the ERP system in JOHUD) where the 
averages ranged from (3.80 and 4.07) comparing to the overall average of this factor that equal (3.92) in which the paragraph (The ERP is an ease to use system) get the first importance level with the average of (4.07) and with (0.44) standard deviation comparing to the overall average (3.92). on the other hand the paragraph (The ERP system can help in achieving employee needs) has get the least importance level with average (3.80) and (0.53) standard deviation, comparing to the overall average (3.92) for the factor of system quality. However the averages of the all the paragraphs were high...

\subsection{Results Presentation of the Factor of Effectiveness of the ERP Systems According To the User Satisfaction}

The standard deviation, average and the level of evaluation of paragraphs have been used to test the factor of ERP effectiveness according to the factor of customer satisfaction. The table bellow present the analysis of the paragraphs about the user satisfaction depending on the response of the study population (centers that uses the ERP system in JOHUD) where the averages ranged from (3.46 and 4.01) comparing to the overall average of this factor that equal (3.92) in which the paragraph (My company helps me in better using of ERP by participating in a ERP presentation) get the first importance level with the average of (4.01) and with (0.76) standard deviation comparing to the overall average (3.76). On the other hand the paragraph (IT department in my company helps in solving the problem that may face the ERP system) has get the least importance level with average (3.46) and (0.85) standard deviation, comparing to the overall average (3.76) for the factor of user satisfaction. However the averages of the all the paragraphs was high.

Table 6. Testing the ERP system effectiveness paragraphs according user satisfaction.

\begin{tabular}{|l|l|l|l|l|l|l|}
\hline The paragraph & Average & $\begin{array}{l}\text { Standard } \\
\text { deviation }\end{array}$ & T test & $\begin{array}{l}\text { Level of } \\
\text { evaluation }\end{array}$ & $\begin{array}{l}\text { The } \\
\text { paragraph }\end{array}$ & $\begin{array}{l}\text { The importance } \\
\text { of paragraph }\end{array}$ \\
\hline $\begin{array}{l}\text { IT department in my } \\
\text { company helps in solving } \\
\text { the problem that may face } \\
\text { the ERP system }\end{array}$ & 3.46 & 0.85 & 40.100 & High & 1 & 2 \\
\hline $\begin{array}{l}\text { My company helps me in } \\
\text { better using of ERP by } \\
\text { participating in a ERP } \\
\text { presentation }\end{array}$ & 4.01 & 0.76 & 52.303 & High & 2 & 1 \\
\hline The overall average & 3.76 & & & & \\
\hline
\end{tabular}

This exercise has strengthened communication and cooperation between the centres, and with JOHUD itself. The cluster approach has also been successful in differentiating between geographical locations and strategic priorities. As we well know, there is no 'one size fits all' solution to the development challenges that communities are facing. Within the three clusters of centres, we are trying to be more sensitive to these varying needs and challenges, and to reflect this awareness in more innovative and responsive projects and programs. 


\section{Hypothesis Testing}

In order to test the research hypothesis the regression and multiplies regression have been used to test the effect of the dependent and independent variable on each other.

Main Hypothesis one: there is NO statistical significant effect of all the factors of ERP effectiveness (system quality, information quality, user satisfaction) altogether on improving the organizational performance.

To test this hypothesis multiple regression have been used to test the effect of all the factors of ERP effectiveness on improving organizational performance in (JOHUD)

The below table identify the results of the multiple regression.

Table 7. H1 multiple regression

\begin{tabular}{|l|l|l|l|}
\hline ERP effectiveness factors & Systems quality & Information quality & User satisfaction \\
\hline$\beta$ value & 0.2 & 0.1 & 0.5 \\
\hline
\end{tabular}

The effect has statistical significances when the level is $(.05 \geq a)$

The correlation coefficient was $=0.75$ and the $\mathrm{F}$ calculated was $=38.22$

The coefficient determination was $=\left(\mathrm{R}_{2}\right) 50$ and the Sig $=0.00$

The table above test the effect of the factors of ERP effectiveness altogether on improving the organizational performance in (JOHUD). The results shows that there is a significant effect of the factors of ERP in improving the organizational performance in which the $\mathrm{R}$ value for all the factors together was 0.75 at the level of $(.05 \geq a)$ and that means that there is an effect of all the factors of ERP effectiveness on improving the organizational performance in (JOHUD). However the determination coefficient was $(0.50)$ and that means that $(0.50)$ of the changes in the organizational performance was because of the changes in the factors of ERP effectiveness. The (Beta) values showed in table (7) above shows the value of effect which means that the increase in one degree in any factor of ERP effectiveness (system quality, information quality and user satisfaction) will result increasing in one degree in improving the organizational performance in $\beta$ value, furthermore the $\mathrm{F}$ calculated value that equal (38.22) also confirm the moral effect of the ERP effectiveness factors on improving the organizational performance also.

All the above values can be used to reject the first hypothesis: there is NO statistical significant effect of all the factors of ERP effectiveness (system quality, information quality, user satisfaction) altogether on improving the organizational performance. And accept the hypothesis that suppose an effect of the ERP factors on organizational performance at the level $(.05 \geq \mathrm{a})$

Sub hypothesis one :( Hol) there is NO statistical significant effect of the information quality on improving organizational performance at the level $(.05 \geq$ a)

In order to test the above hypothesis the simple regression have been used in order to test the effect of information quality on improving organizational performance, furthermore the $\left(\mathrm{R}_{2}\right)$ 
have been used to explain the effect among the dependent and independent factor.

Table 8 . Ho1 testing values

\begin{tabular}{|c|c|c|c|c|c|}
\hline $\begin{array}{l}\text { The effect of information quality } \\
\text { on improving organizational }\end{array}$ & $\begin{array}{l}\text { Correlation } \\
\text { Coefficient }\end{array}$ & $\begin{array}{l}\text { Coefficient of } \\
\text { determination (R2) }\end{array}$ & $\begin{array}{l}\mathrm{F} \\
\text { calculated }\end{array}$ & $\begin{array}{l}(\beta) \text { Regression } \\
\text { coefficient }\end{array}$ & Sig \\
\hline performance & 0.56 & 0.33 & 44.2 & 0.58 & 0.00 \\
\hline
\end{tabular}

The effect can be considered as statistically significant at the level of $(.05 \geq a)$

The table above shows a statistical significant effect of information quality on improving organizational performance in which the correlation coefficient was 0.56 at the level of $(.05 \geq a)$. However the $\left(R_{2}\right)$ coefficient determination was 0.33 that means that $(0.33)$ from the changes on improving organizational performance comes as a result from the change in information quality of ERP system in (JOHUD). The $\beta$ beta on the other hand was $(0.58)$ that means statistically that an increase with one degree in information quality of ERP will result in increase in (0.58) in improving the organizational performance.

The (F) calculated that were (44.2) confirming the moral effect of the information quality of ERP system on improving the organizational performance.

Sub hypothesis two :( Ho2) there is NO statistical significant effect of the systems quality on improving organizational performance at the level $(.05 \geq a)$

In order to test the above hypothesis the simple regression have been used in order to test the effect of systems quality on improving organizational performance, furthermore the $\left(\mathrm{R}_{2}\right)$ have been used to explain the effect among the dependent and independent factor.

Table 9. Ho2 testing values

\begin{tabular}{|c|c|c|c|c|c|}
\hline \multirow{2}{*}{$\begin{array}{l}\text { The effect of systems quality on } \\
\text { improving organizational } \\
\text { performance }\end{array}$} & $\begin{array}{l}\text { Correlation } \\
\text { Coefficient }\end{array}$ & $\begin{array}{l}\text { Coefficient of } \\
\text { determination (R2) }\end{array}$ & $\begin{array}{l}\mathrm{F} \\
\text { calculated }\end{array}$ & $\begin{array}{l}(\beta) \text { Regression } \\
\text { coefficient }\end{array}$ & Sig \\
\hline & 0.70 & 0.50 & 86.2 & 0.70 & 0.00 \\
\hline
\end{tabular}

The effect of systems quality on improving organizational performance can be considered as statistically significant at the level of $(.05 \geq a)$

The table above shows a statistical significant effect of systems quality on improving organizational performance in which the correlation coefficient was 0.70 at the level of $(.05 \geq$

a). However the $\left(\mathrm{R}_{2}\right)$ coefficient determination was 0.50 that means that $(0.50)$ from the changes on improving organizational performance comes as a result from the change in systems quality of ERP system in (JOHUD). However the $\beta$ beta was (0.70) and that means statistically that an increase with one degree in systems quality of ERP will result in increase in (0.70) in improving the organizational performance. The $(\mathrm{F})$ calculated that were (86.2) confirming the moral effect of the systems quality of ERP system on improving the organizational performance. 
Sub hypothesis three :( Ho3) there is NO statistical significant effect of user satisfaction on improving organizational performance at the level $(.05 \geq a)$

In order to test the above hypothesis the simple regression have been used in order to test the effect of user satisfaction on improving organizational performance, furthermore the $\left(\mathrm{R}_{2}\right)$ have been used to explain the effect among the dependent and independent factor.

Table 10. Ho3 testing values

\begin{tabular}{|l|l|l|l|l|l|}
\hline $\begin{array}{l}\text { The effect of user satisfaction on } \\
\text { improving } \begin{array}{l}\text { organizational } \\
\text { performance }\end{array}\end{array}$ & $\begin{array}{l}\text { Correlation } \\
\text { Coefficient }\end{array}$ & $\begin{array}{l}\text { Coefficient of } \\
\text { determination (R2) }\end{array}$ & $\begin{array}{l}\text { F } \\
\text { calculated }\end{array}$ & $\begin{array}{l}(\beta) \text { Regression } \\
\text { coefficient }\end{array}$ & Sig \\
\cline { 2 - 7 } & 0.52 & 0.27 & 32.2 & 0.52 & 0.00 \\
\hline
\end{tabular}

The effect of user satisfaction on improving organizational performance can be considered as statistically significant at the level of $(.05 \geq a)$

Table (10) above shows a statistical significant effect of user satisfaction on improving organizational performance in which the correlation coefficient was 0.52 at the level of $(.05 \geq$

a). However the $\left(\mathrm{R}_{2}\right)$ coefficient determination was 0.27 and that means that $(0.52)$ from

the changes on improving organizational performance comes as a result from the change in user satisfaction of ERP system in (JOHUD). However the $\beta$ beta was (0.52) and that means statistically that an increase with one degree in user satisfaction of ERP system will result in increase in (0.52) in improving the organizational performance.

The (F) calculated that were (32.2) confirming the moral effect of user satisfaction of ERP system on improving the organizational performance.

\section{Results and Conclusion}

The study aims at answering the main hypothesis and it found many answers that help in understand the research problem; the most important result was that the information quality of ERP system has a noticeable and high effect on the organizational performance in which the average was (4.02) it was in the first level comparing to the other factors used in the study; systems quality and user satisfaction. This result indicate the importance of information quality provided by the ERP system for the system user, furthermore the study found that the level of the effect of systems quality have the second level after the information quality comparing to the other factors used in the study, in which the average for this factor was (3.92). As for the user satisfaction of ERP system have the third and least level of effect on organizational performance comparing to the other factors used in the study in which the average for this factor was (4.03).

As a result of all the above indicators the main finding for this study was that there is a statistical and noticeable effect of ERP effectiveness factors all together (information quality, systems quality and user satisfaction) on organizational performance at statistical acceptance level of $(.05 \geq a)$. On the other hand each factor of ERP effectiveness separately ((information quality, systems quality and user satisfaction) has an effect on organizational performance at the statistical acceptance level of (.05 $\geq a)$. 
By using all the above results the study recommends the companies that aim to achieve best results of using ERP system to put on its consideration the factors of ERP effectiveness ( information quality, systems quality and user satisfaction ). However in order to achieve best results of ERP systems users must be well trained and developed to use the system in a better way, the well trained and educated human resource is one of the most important resource in Jordan but it still needs more training about the use of ERP system. User involvement in ERP system may also help in providing more effective ERP that leads for better organizational performance in (JOHUD).

The study also recommend the IT department in (JOHUD) to try to find better solution for the ERP user problems and that maybe achieved more by user involvement.

\section{Reference}

Ababneh, R. A. (2008). A Comprehensive Performance Evaluation of the Jordanian Customs Department Using the Balanced Scorecard. Jordan Journal of Business Administration, 4(4).

Alexander Cedric (2009). Case Study: Exploring the effectiveness of ERP Integration towards managerial performance. (Doctoral dissertation), Capella university. Minneapolis, Minnesota, USA.

Andreu, R., \& Ciborra, C. (1996). Organizational Learning and Core Capabilities Development: The Role of IT. Journal of Strategic Information Systems, 5(2), 111-127. http://dx.doi.org/10.1016/S0963-8687(96)80039-4

Atiyyah,Hamid S.(1989).Determinants of computer system effectiveness in Saudi Arabian public organization, Int. Studies of Mgt. \& Org., 19(2), 85-103. http://dx.doi.org/10.1080/00208825.1989.11656506

Ayyagari, R. A. (2010). Hands-on ERP Learning: Using Open ERP, an Alternative to SAP. Journal of Information Systems Education, 22(2).

Barley, Stephen R. (1990). The Alignment of Technology and Structure through Roles and Networks, Administrative Science Quarterly, 35(1), 61-103. http://dx.doi.org/10.2307/2393551

Barney, J. B. (1991). Firm Resources and Sustained Competitive Advantage. Journal of Management, 17(1), 99-120. http://dx.doi.org/10.1177/014920639101700108

Beard, J. W., \& Sumner, M. (2004). Seeking Strategic Advantage in the Post-Net Era: Viewing ERP Systems from the Resource-Based Perspective. The Journal of Strategic Information Systems, 13(2), 129-150. http://dx.doi.org/10.1016/j.jsis.2004.02.003

Bendoly, E., \& Kaefer, F. (2004). Business Technology Complementarities: Impacts of the Presence and Strategic Timing of ERP on B2B E-commerce Technologies Efficiencies. The International Journal of Management Science, 32(5), 395-405. http://dx.doi.org/10.1016/j.omega.2004.02.004

Chian-Son Yu, (2005). Causes influencing the effectiveness of the post-implementation ERP 
system, Industrial Management \& Data Systems, 105(1), 115-132. http://dx.doi.org/10.1108/02635570510575225

Delone, H., \& Mclean, R (2003). The DeLone and McLean Model of Information systems Success: A Ten-Year Update. Journal of Management Information Systems, 19(4), 9-30.

Dumitru, F., Albu, N., Albu C, \& Dumitru M, (2013). ERP implementation and organizational performance, A Romanian case study of best practice. Amfiteatru Economic. Vol xv. No. 34.

Etezady, N., (2008). The impact of ERP investments on organizational performance. Ph.D. Thesis NOVA SOUTHEASTERN UNIVERSITY, 186 pages; 3311296.

Fosser, E, Leister, O, Moe, CE, \& Newman, M, (2008). Organisations and Vanilla Software: What Do We Know About ERP Systems and Competitive Advantage? ECIS 2008 Proceedings. Paper 132

Hansen, G. S., \& Wernerfelt, B. (1989). Determinants of firm performance: The relative importance of economic and organizational factors. Strat. Mgmt. J., 10, 399-411. http://dx.doi.org/10.1002/smj.4250100502

Hassabelnaby, Hassan R. David, \& Vonderembse, Mark A. (2012). The Impact of ERP Implementation on Organizational Capabilities and Firm Performance. Benchmarking: the International Journal, 19, 2012.

Holland, C., Light, B., \& Kawalek, P. (1999). Beyond Enterprise Resource Planning Projects: Innovative Strategies for Competitive Advantage. Proceedings of the $7^{\text {th }}$ European Conference on Information Systems, 1, 288-301.

Holland, C. P., \& Light, B. (1999). A Critical Success Factors Model for ERP Implementation. IEEE Software, 16(3), 30-36. http://dx.doi.org/10.1109/52.765784

Holland, W., \& Skarke, G. (2001). Is your IT system VESTed? Strategic Finance, 83(6), 34-38.

Kalling, T. (2003). ERP Systems and the Strategic Management Processes that Lead to Competitive Advantage. Information Resources Management Journal, 16(4), 46-67. http://dx.doi.org/10.4018/irmj.2003100104

Klenke, Karin, (1992). Construct measurement in management information systems: A review and critique of user satisfaction and user involvement instruments. Information system. 30(4), 325-348.

Lengnick-Hall, C. A., Lengnick-Hall, M. L., \& Abdinnour-Helm, S. (2004). The Role of Social and Intellectual Capital in Achieving Competitive Advantage through Enterprise Resource Planning (ERP) Systems. Journal of Engineering and Technology Management, 21(4), 307-330. http://dx.doi.org/10.1016/j.jengtecman.2004.09.005

Light, B., \& E. L. Wagner. (2006). Integration in ERP Environments: Rhetoric, Realities and Organizational Possibilities. New Technology, Work and Employment, 21(3), 215- 228. http://dx.doi.org/10.1111/j.1468-005X.2006.00176.x 


\section{Mll Macrothink}

Business and Economic Research ISSN 2162-4860 2016, Vol. 6, No. 1

Markus, M. L., \& Tanis, C. (2000). The Enterprise Systems Experience-From Adoption to Success, Zmud, R.W. (Ed.) Framing the Domains of IT Research: Glimpsing the Future through the Past. Pinnaflex Educational Resources, Cincinnati.

Mata, F. J., Fuerst, W. L., \& Barney, J. B. (1995). Information Technology and Sustaining Competitive Advantage: A Resource-based Analysis. MIS Quarterly, 19(4), 487-505. http://dx.doi.org/10.2307/249630

M. Lynne Markus, Sheryl Axline, David Petrie, \& Sheryl Cornelis Tanis. (2000). learning from adopters' experiences with ERP: problems encountered and success achieved. Journal of Information Technology, 15(4), 245-265. http://dx.doi.org/10.1080/02683960010008944

Nicolaou, Andreas, \& Bhattacharya (2006). Organizational performance effects of ERP systems usage: The impact of post-implementation changes. International Journal of Accounting Information Systems. 7(1), 18-35. http://dx.doi.org/10.1016/j.accinf.2005.12.002

Nooredin Etezady. (2011). The Impact of ERP Investments on Organizational Performance" International Journal of the Academic Business World, 5(2), 27-33.

Palanisamy, Ramaraj. \& Sushil. (2001). Empirically testing the Relationship between user involvement, information waste, and MIS Success. Journal of services Research. 1(1), ApriSeptember, 70-103.

Princely Ifinedo, Nazmun Nahar, (2009). Interactions between contingency, organizational IT factors, and ERP success, Industrial Management \& Data Systems, 109(1), 118-137. http://dx.doi.org/10.1108/02635570910926627

Raymond, Louis. (1985). Organizational characteristics and MIS success in the context of small business. MIS quarterly/March, 37-52. 13. http://dx.doi.org/10.2307/249272

Tsai, W., Chen, S., Hwang, E., \& Hsu, J. (2010). A Study of the Impact of Business Process on the ERP System Effectiveness. International Journal of Business and Management. 5(9), 26-37. http://dx.doi.org/10.5539/ijbm.v5n9p26

\section{Copyright Disclaimer}

Copyright for this article is retained by the author(s), with first publication rights granted to the journal.

This is an open-access article distributed under the terms and conditions of the Creative Commons Attribution license (http://creativecommons.org/licenses/by/3.0/). 